\title{
GENETIC RESOURCES OF CHICKPEA AND THE EFFECTIVENESS OF THEIR USE IN BREEDING
}

\author{
Viacheslav Sichkar $^{1}$, Anna Kryvenko ${ }^{1 *}$, Ruslan Solomonov ${ }^{1}$ \\ ${ }^{1 *}$ Odessa State Agricultural Research Station of NAAS, Ukraine; \\ *Corresponding Author Anna Kryvenko, e-mail: kryvenko35@ukr.net;
}

Received September 2020; Accepted October 2020; Published November 2020;

DOI: https://doi.org/10.31407/ijees10.426

\begin{abstract}
The article summarizes the characteristics of economically valuable features of a large set of chickpea samples in arid conditions of the steppe of Ukraine. The data on the spread of culture on our planet shows the positive impact of food made from its seeds on human health. A number of genotypes have been identified and described, which combine a significant number of important agronomic traits that are of significant value for breeding. Special attention in the research was paid to the identification of genotypes tolerant to elevated air temperatures and insufficient moisture in the soil. A brief description of the varieties created with the participation of exotic genetic plasma is given. As a result of many years of study of accessions of chickpea, sources of increased seed productivity, large seeds, high protein content, tolerance against pathogens, improved technological qualities of seeds have been identified. Individual genotypes have been identified in which several economically valuable indicators have been improved. It is shown that the combination of traits of samples of different ecological and geographical origin in one genotype has a high probability of obtaining valuable recombinant forms by accumulating positive adaptive genes. A particularly wide variation of breeding material is needed to prevent disease outbreaks and the widespread of pests, the danger of which increases significantly with the homogeneity of the gene pool.
\end{abstract}

Keywords: chickpea, collection samples, vegetation duration, drought tolerance, protein content, seed size. 